\title{
Advocacy through images: Dorothea Lange
}

\section{Richard B. Gunderman ${ }^{1}$}

Received: 20 December 2019 / Revised: 20 December 2019 / Accepted: 24 January 2020 /Published online: 11 February 2020

(C) Springer-Verlag GmbH Germany, part of Springer Nature 2020

Pediatric radiologists and photographers are imagers, and both can use the images they create for purposes of advocacy. To understand how effectively images can advance advocacy, radiologists can turn to few better sources of inspiration than Dorothea Lange. She was one of the 20th century's bestknown American photographers and created perhaps its most iconic image: "Migrant Mother." Her images of impoverished, hungry and even incarcerated children may have done more than the words of any journalist or politician to foster public sympathy for their plight, in large part because she knew firsthand what loss was all about.

\section{Early years}

Lange was born in New Jersey in 1895, the year that X-rays were discovered in the land of her grandparents. They emigrated from Germany in the 1850s, and her parents grew up in Hoboken, her father a lawyer and her mother a voice soloist. When Lange was 7 years old, she contracted polio. At the time, fearful neighbors often shunned people with polio and their families. Although Lange survived, she was left with a lifelong limp. Lange's mother used to chide her to "walk as well as you can," which also left her with a lifelong antipathy to what other people thought. She became known as "Limpy," later saying that the disease "guided me, instructed me, helped me, and humiliated me" [1].

When Lange was 12 , her family was evicted from their home. Her father vanished, and her mother, she and her younger brother were forced to take lodging with their grandmother. Lange's mother took a job as a librarian in Manhattan, and Lange found herself the only non-Jew at her public school of 3,000 Jewish students. While Lange waited for her mother to

Richard B. Gunderman

rbgunder@iu.edu

1 Department of Radiology, Indiana University School of Medicine, 702 North Barnhill Drive, Room 1053, Indianapolis, IN 46077, USA pick her up after school, she read books in the school library. Some days she walked home alone through The Bowery, and she was so afraid of the often-intoxicated men lining the streets that she developed what she called her "cloak of invisibility," a strategy for making herself as unnoticeable as possible.

\section{Photography}

Though a distracted student, Lange managed to graduate from high school. When her mother asked her what she wanted to do next, she replied that she wanted to be a photographer, even though she had never owned a camera or even taken a picture. She got a job at a portrait studio, first answering phones and later retouching photographs. Soon she learned the use of big studio cameras and how to operate a dark room. Eventually she enrolled in a photography class at Columbia University, where she imbibed the instructor's conviction that everyday life should be captured on film. Later she and a friend embarked on a round-the-world voyage, but their money was stolen in San Francisco.

Stranded, Lange took a job at a photography counter and abandoned her father's name - Nutzhorn - to become known as Dorothea Lange. Within months she received a loan to open her own studio. There her business, which attracted wealthy patrons, thrived. Artists gathered at her studio, and one, Maynard Dixon, though he was 45 and she 24, became her husband. Dixon, who had been a muralist, became a portrait painter. They traveled to Arizona, where for the first time she saw and photographed "Indians, Mexicans and poor whites" who sustained themselves by bartering in the town square [1]. Over the next few years, Lange bore two sons.

In 1929 the stock market crashed, and their lives changed dramatically. They moved to New Mexico. There she drove Dixon to the studio, then spent her day caring for the boys. When they returned to San Francisco, she realized that her bond with Dixon had weakened and they soon divorced. Though she sustained herself through making portraits of 
her wealthy clientele, she became more and more acutely aware of the poor and unemployed people all around her. She took her camera and headed for the slums, and over the ensuing months found herself spending more and more time there. During a 1934 demonstration, she photographed a man at a microphone, which became her first paid work outside the studio.

\section{Advocacy}

Lange soon met Paul Taylor, an economist who studied the plight of migrant farm workers. As people from Oklahoma fleeing the Dust Bowl poured into the state, Taylor encouraged her to photograph them. They began traveling to California towns such as Nipomo to document the lives of pea pickers. Soon they fell in love and were married. Life in the camps would be documented in one of the great American novels, John Steinbeck's 1939 The Grapes of Wrath. It was at one such camp in 1936 that Lange took her most famous photograph, "Migrant Mother" (Fig. 1). Taylor urged the government to improve migrant living conditions, but farmers and townspeople opposed such improvements.

Lange and Taylor eventually moved to Berkeley, CA, where she managed a household of two of her own children and three stepchildren. In the summers, Lange and Taylor boarded the children with other families so they could travel, documenting the conditions of the Depression-era poor for the Farm Security Administration. One summer Lange logged more than 17,000 miles. Many people who once owned land had been reduced to sporadic labor and were unable to feed

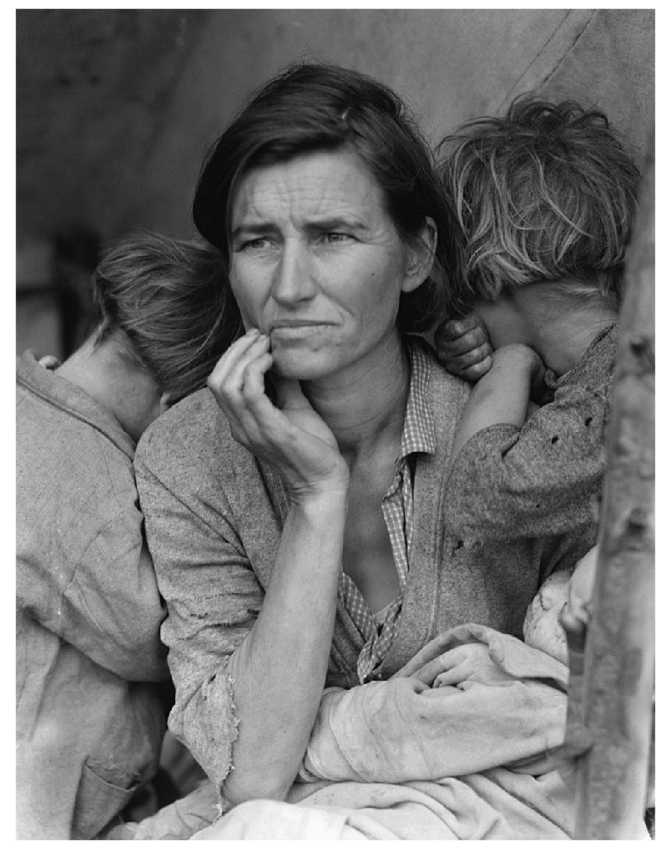

Fig. 1 “Migrant Mother," photo by Dorothea Lange, 1936 their families. In the South, where poll taxes and literacy tests were the rule, more than half of the white families and virtually all the black families were unable to vote.

\section{Later years}

When Steinbeck's novel was introduced, Lange redoubled her efforts to publish a book whose images would document the lives Steinbeck so poignantly described. Her book, American Exodus, was published in 1940. Shortly thereafter, as America's attention shifted to World War II, budget cuts cost Lange her job, and her book fell flat. In 1941, she received a Guggenheim Fellowship, the first awarded to a woman in photography. A year later, President Franklin D. Roosevelt signed an order establishing concentration camps for Japanese Americans. Relinquishing her fellowship, Lange worked for the War Relocation Authority, documenting the internment. The Army impounded most of her images during the war.

After the war, photographer Ansel Adams invited Lange to teach at the California School of Fine Arts. In 1952, she founded a photography journal, Aperture. She received numerous commissions from Life magazine, such as "Mormon Villages" and "The Irish Countryman," and her work was displayed at the Art Institute of Chicago and the Museum of Modern Art in New York. Lange's health declined through most of the 1950s and '60s, and she died of esophageal cancer in 1965 . Her remains were cremated and her ashes scattered. She was survived by Taylor, her two children and three stepchildren, and numerous grandchildren.

\section{Lessons for advocates}

Of her photo "Migrant Mother" (Fig. 1), Lange wrote,

I saw and approached the hungry and desperate mother, as if drawn by a magnet. I do not remember how I explained my presence or my camera to her, but I do remember she asked me no questions. I made five exposures, working closer and closer from the same direction. I did not ask her name or her history. She told me her age, that she was thirty-two. She said that they had been living on frozen vegetables from the surrounding fields, and birds that the children killed. She had just sold the tires from her car to buy food. There she sat in that lean-to tent with her children huddled around her, and she seemed to know that my pictures might help her, and so she helped me. There was a sort of equality about it [2]. 
The photograph depicts a family's humble living space. At the center of the image is the mother, to whose eyes the viewer's are inexorably drawn. Her hand is drawn up to her mouth, and her expression is one of evident concern. She holds a baby in her arms. She is flanked by two daughters, both of whom are turned away from the camera. We get the sense that only the mother can bear to look at the misery that lies before them, a sight the children cannot ever bear to behold. In an irony even Lange might have found difficult, after she captured the photo, she went on to become a famous photographer, never to see or interact again with the subject of her most famous work.

Lange focused her lens not on the wealthy, famous or powerful, but on ordinary people, and especially children and the impoverished. In photographing them, she used the same techniques of composition that she had perfected with San Francisco's elite, imbuing their lives with significance. Her early life had taught her what it means to be marginalized, and her images show people on the margins not as pathetic or powerless but as dignified and possessed of a quiet strength. Those who had witnessed the intimacy of her images would find it more difficult to dismiss the nameless and property-less as "the poor." Instead they would see human beings as no less distinct and substantial than the elite.

As she wrote years later, "The camera is an instrument that teaches people how to see without a camera" [3]. Through her lens, she could teach viewers what is worth noticing and how to look. And she could engage not only eyes but also hearts and eventually minds and hands to reach out to those in need, especially children. Whether on the streets of a big city, in tents in migrant farm camps, or preparing to board buses to internment camps, Lange saw in the faces of the most vulnerable the dignity of all humanity. Pediatric radiologists, imagers of another sort, can answer a similar call, ensuring that voiceless children and their stories do not languish from neglect.

\section{Compliance with ethical standards}

Conflicts of interest None

\section{References}

1. Partridge E (2013) Dorothea Lange: grab a hunk of lightning. Chronicle Books, San Francisco

2. Lange D (1936) Migrant mother, Nipomo, California. https://www. moma.org/learn/moma_learning/dorothea-lange-migrant-mothernipomo-california-1936/. Accessed 15 Jan 2020

3. Detroit Public TV (2014) Dorothea Lange: grab a hunk of lightning: quotes by Dorothea Lange. American Masters. http://www.pbs.org/ wnet/americanmasters/dorothea-lange-quotes-by-dorothea-lange/ 3159/. Accessed 15 Jan 2020

Publisher's note Springer Nature remains neutral with regard to jurisdictional claims in published maps and institutional affiliations. 